\title{
LONG-TERM CHANGES IN THICKNESS OF BICEPS TENDON AND ROTATOR CUFF AT DIFFERENT STAGES OF FUNCTIONAL RECOVERY OF HEMIPLEGIC SHOULDER- AN OBSERVATIONAL STUDY
}

\author{
Pradeep Kumar Kalathil' ${ }^{1}$ S. Abdul Gafoor ${ }^{2}$, T. K. Vasudevan³, P. C. Muralidharan ${ }^{4}$, Sreejith $K^{5}$ \\ 1Junior Consultant, Department of Physical Medicine and Rehabilitation, District Hospital, Vadakara, Kozhikode, Kerala, India. \\ 2 Professor and HOD, Department of Physical Medicine and Rehabilitation, GMC, Kottayam, Kerala, India. \\ 3 Professor, Department of Physical Medicine and Rehabilitation, GMC, Kozhikode Kerala, India. \\ ${ }^{4}$ Assistant Professor, Department of Physical Medicine and Rehabilitation, GMC, Kottayam, Kerala, India. \\ ${ }_{5}^{5}$ Associate Professor, Department of Physical Medicine and Rehabilitation, GMC, Kottayam, Kerala, India.
}

\section{ABSTRACT}

\section{BACKGROUND}

Shoulder pain and stiffness is a common problem after stroke. Many types of shoulder pathology after stroke have been reported. Ultrasonography can diagnose most of the pathologies in and around the shoulder.

Aims and Objectives-To study the relationship of biceps tendon thickness and rotator cuff thickness at different stages of functional recovery of hemiplegic shoulder.

\section{MATERIALS AND METHODS}

This is a prospective observational study of patients with hemiplegic shoulder attending the outpatient clinic of physical medicine and rehabilitation, GMC, Kozhikode. Adult stroke patients irrespective of duration of stroke, who were willing to give an informed valid consent, were included in the study.

\section{RESULTS}

Most common ultrasonographic soft tissue pathological changes in hemiplegic shoulder were bicipital tendinitis and rotator cuff tendinitis thereby increasing the thickness of corresponding tendon. There was significant reduction in thickness of these structures following a structured rehabilitation program.

\section{CONCLUSION}

Soft tissue ultrasonography can be used in diagnosis of shoulder pain in hemiplegia. Serial evaluation helps in tailoring a structured rehabilitation program.

\section{KEY WORDS}

Rotator Cuff, Ultrasonography, Hemiplegic Shoulder.

HOW TO CITE THIS ARTICLE: Kalathil PK, Gafoor SA, Vasudevan TK, et al. Long-term changes in thickness of biceps tendon and rotator cuff at different stages of functional recovery of hemiplegic shoulder- an observational study. J. Evolution Med. Dent. Sci. 2018;7(52):5501-5505, DOI: $10.14260 /$ jemds/2018/1217

\section{BACKGROUND}

Stroke is a clinical syndrome characterized by sudden development of a persisting focal neurological deficit following disturbance in blood supply to the brain due to ischemia or haemorrhage. It is the most common serious neurological disorder, being the third leading cause of death after heart disease and cancer. It has been identified as a major public health problem in recent decades in India due to its i) increasing incidence, ii) morbidity and disability, iii) increasing incidence of hypertension, diabetes, dyslipidaemia, alcoholism and iv) increasing ageing population ${ }^{1}$. Incidence is age related, being relatively uncommon before age 50 , but doubling each decade after age 55 . Stroke is more common in men.

'Financial or Other Competing Interest': None.

Submission 15-11-2018, Peer Review 11-12-2018,

Acceptance 17-12-2018, Published 24-12-2018.

Corresponding Author:

Dr. S. Abdul Gafoor

Professor and HOD,

Department of Physical Medicine and Rehabilitation,

GMC, Kottayam, Kerala, India.

E-mail: drsagafoor@gmail.com

DOI: $10.14260 /$ jemds $/ 2018 / 1217$

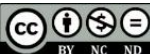

The Modifiable Risk Factors for Stroke are Hypertension, Heart disease, Smoking, Diabetes mellitus, Elevated fibrinogen, Erythrocytosis, Hyperlipidaemia etc.

The overall mortality from stroke is declining, due to better risk-factor reduction and better medical management of patients during the acute phase. It should be noted that longterm post stroke survival is improving, and therefore, prevalence of stroke in the population has stayed the same or has increased.

.A comprehensive rehabilitation program is justified when the patient has a) stable neurologic status, b) Significant persisting neurologic deficit, c) Disability affecting at least two of the following domains: mobility, self-care activities, communication, bowel or bladder control, or swallowing, d) Sufficient cognitive function to learn, e) Sufficient communicative ability to engage with the rehab team personnel, f) Physical ability to tolerate the active program, and g) Achievable therapeutic goals. The rehabilitation program may be offered in different settings, such as an acute inpatient rehabilitation unit, a subacute rehabilitation inpatient unit, home care, or an outpatient centre.

Most patients with significant neurologic impairment who survive a stroke are dependent in basic ADLs, that is; bathing, dressing, feeding, toileting, grooming, and transfers. Almost all patients show improved function in ADLs as recovery occurs. 
Good shoulder function is a prerequisite for successful transfers, maintaining balance, performing activities of daily living and for effective hand function ${ }^{1}$. Shoulder disability is a common complication after stroke and has a significant impact on patient rehabilitation. Shoulder pain and stiffness are the major impairments in a hemiplegic shoulder. Shoulder pain has been associated with severe motor impairment, sensory impairment, duration of hemiplegia, and decreased shoulder range of motion. ${ }^{2}$ Depression, decreased sensation to light touch and temperature has also been associated with shoulder pain. ${ }^{3}$ Rajaratnam et al. identified three factors that predict, with $98 \%$ accuracy, the development of hemiplegic shoulder pain following acute stroke: a positive Neer test, moderate or greater shoulder pain during the performance of the hand behind the neck manoeuvre and a difference of greater than 10 degrees of passive external rotation at the shoulder joint. ${ }^{4}$

Many types of shoulder pathology after stroke have been reported in the literature. No single type of pathology can account for all shoulder problems after stroke. Conversely, more than one type of shoulder pathology may cause pain or stiffness within an individual stroke survivor. The pathogenesis of post-stroke shoulder pain has not been studied rigorously and remains controversial.

Different pathologies for hemiplegic shoulder involvement have been reported, including tendonitis, bursitis, rotator cuff injury, shoulder subluxation, capsulitis, impingement syndrome, complex regional pain syndrome (CRPS), brachial plexopathy, and spasticity. This wide spectrum of diagnoses undoubtedly results from a diversity of underlying pathophysiologies. Physiologic common denominators may exist, however.

Conventional radiographs remain the first step in evaluating a patient with shoulder pain as the clinical signs and symptoms of rotator cuff syndromes are nonspecific and neoplasms of bone or soft tissues can mimic rotator cuff pathology. However, radiography is unable to make a definite diagnosis in majority of cases. ${ }^{5}$ Arthrography is accurate in detection of full thickness tears but is inaccurate in the assessment of tear size and it cannot detect bursal surface partial thickness tears. ${ }^{6}$

In a recent study, the first of its kind, MRI was used to examine a potential association between structural changes in hemiplegic shoulder and pain. ${ }^{7}$ In a series of 89 patients with shoulder pain, $35 \%$ of subjects exhibited a tear of at least one rotator cuff, biceps or deltoid muscle and 53\% exhibited tendinopathy of at least one rotator cuff, bicep or deltoid muscle, rotator cuff tears and rotator cuff and deltoid tendinopathies. Yet, these changes were not related to severity of shoulder pain. Also, MRI has difficulty in distinguishing tears from degeneration of the cuff.

Ultrasound is a low cost, accurate technique in detection and grading of pathology involving the tendons of the rotator cuff. In fact, shoulder joint is probably the most accessible joint for sonography in the adult. Ultrasound has the added advantage of offering a dynamic examination enabling an assessment of the range of movement at the shoulder.

A negative sonogram obtained by an experienced sonologist has been correlated with a good prognosis. Accurate choice can be made between conservative options, arthroscopy and limited or extensive open surgical techniques. Ultrasound is accurate in evaluating the size and site of rotator cuff tears.
Sonography has the advantage of multiplanar imaging without the need for reformatting. It is also superior to CT in the diagnosis of fine calcific deposits. Radiation protection considerations are also important, particularly where repeat investigations are required or screening for chronic injury or disease. Sonographic soft tissue contrast resolution is far greater than conventional radiography or even CT, since it is not dependent on fat planes or contrast enhancement agents. MRI provides greater inter tissue soft tissue contrast resolution than ultrasound. However, it usually provides inferior intra-tissue contrast. High frequency transducers provide significantly superior spatial resolution to MRI. Ultrasound has advantages like availability and portability, real time dynamic functional studies, speed of investigation, patient acceptability and cost effectiveness.

\section{Management of Hemiplegic Shoulder}

Despite the high prevalence of patients suffering from painful hemiplegic shoulders, the evidence for effective treatment is underwhelming and no particular intervention appears superior. There is conflicting evidence that electrical stimulation helps to reduce pain and subluxation, and conflicting evidence that botulinum toxin can help to reduce pain or spasticity. There is moderate evidence supporting an active therapy-oriented approach, although overaggressive therapies using pullies substantially increases pain when compared to gentler range of motion therapy approaches. There is insufficient evidence that positioning of the shoulder or shoulder strapping prevent subluxation, decrease pain or increase functionality.

There is consensus opinion that prevention and avoidance of overaggressive therapy is important. Those individuals caring for the stroke patient, particularly early on, should be aware of the potential for shoulder injury. The shoulder should be carefully positioned and supported against gravity while sitting or standing. Range of motion exercises should not carry the shoulder beyond 90 degrees of flexion and abduction unless there is upward rotation of the scapula and external rotation of the humeral head 8 .

\section{Aims and Objectives}

1. To assess the changes in USG findings of soft tissues at different stages of functional recovery.

2. To find out the relationship of Biceps tendon thickness with Rotator cuff thickness at different stages of functional recovery.

\section{MATERIALS AND METHODS \\ Design}

Prospective observational study.

\section{Settings}

Patients with stroke attending at the outpatient clinic of Dept. of Physical Medicine and Rehabilitation, Govt. Medical College, Kozhikode.

\section{Study Tool}

Adult stroke patients irrespective of duration of stroke, who were willing to give an informed valid consent, were included in the study.

\section{Inclusion Criteria}

- $\quad$ Both males and females having first stroke, resulting in unilateral hemiplegia. 
- No history of shoulder impairment in the past 6 months prior to stroke.

\section{Exclusion Criteria}

- Restroke patients.

- Past history of shoulder impairment within the past six months.

- Cognitive impairment that impedes communication.

\section{Outcome Variables}

Soft tissue changes in musculoskeletal ultrasonography (Measured in millimetres).

\section{Statistical Analysis}

Statistical analysis was done by using SPSS 10 software. Correlations were assessed using Pearson correlation coefficient. Repeat measure of ANOVA was used to compare the mean changes of soft tissue thickness over 4 visits. If it is significant a post hoc comparison was used using paired-t test between any two visits. $P$ value of $\leq 0.05$ was considered as statistically Significant

The equipment used in this study is Esaote MyLab 40 with a high frequency linear array transducer (18-MHz) having Doppler capabilities. These transducers demonstrate marked improvement in near-field resolution compared with other devices. In addition, the broad superficial field of view is helpful in evaluating superficial structures.
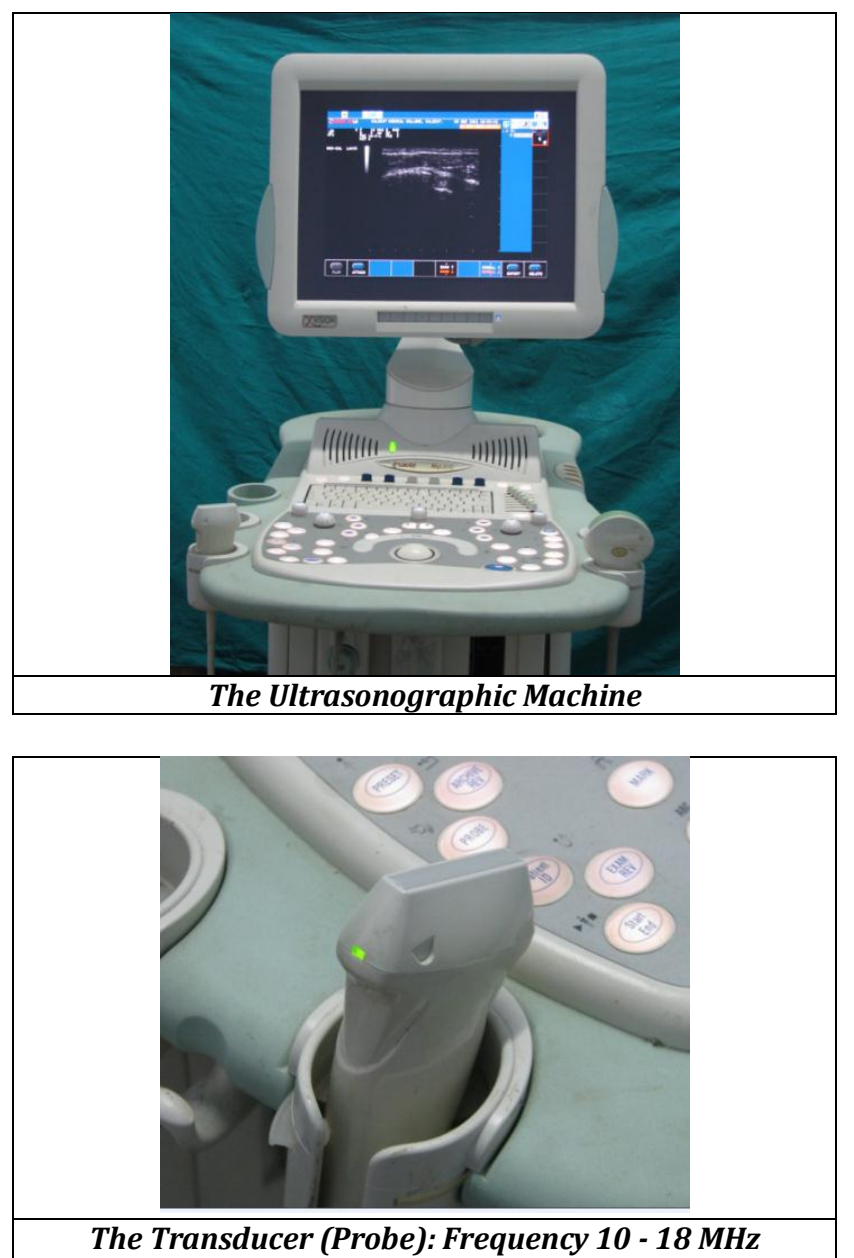

\section{Positioning of Patient}

The patient is scanned while being seated on a revolving stool that permits easy positioning during the scanning of both shoulders. The examiner is also seated on a stool, preferably with wheels to enhance mobility. Both shoulders are examined, starting with the less symptomatic side. This allows comparison views and the detection of asymptomatic tears. Always visualize normal and abnormal anatomy in two orthogonal planes

\section{RESULTS}

\begin{tabular}{|c|c|c|}
\hline Sl. No. & Age & Frequency \\
\hline 1 & $20-29$ & 1 \\
\hline 2 & $30-39$ & 5 \\
\hline 3 & $40-49$ & 4 \\
\hline 4 & $50-59$ & 6 \\
\hline 5 & $60-69$ & 10 \\
\hline 6 & $70-79$ & 7 \\
\hline 7 & $80-89$ & 2 \\
\hline \multicolumn{2}{|c|}{ Table I. Age Distribution of Patients in the Study } \\
\hline
\end{tabular}

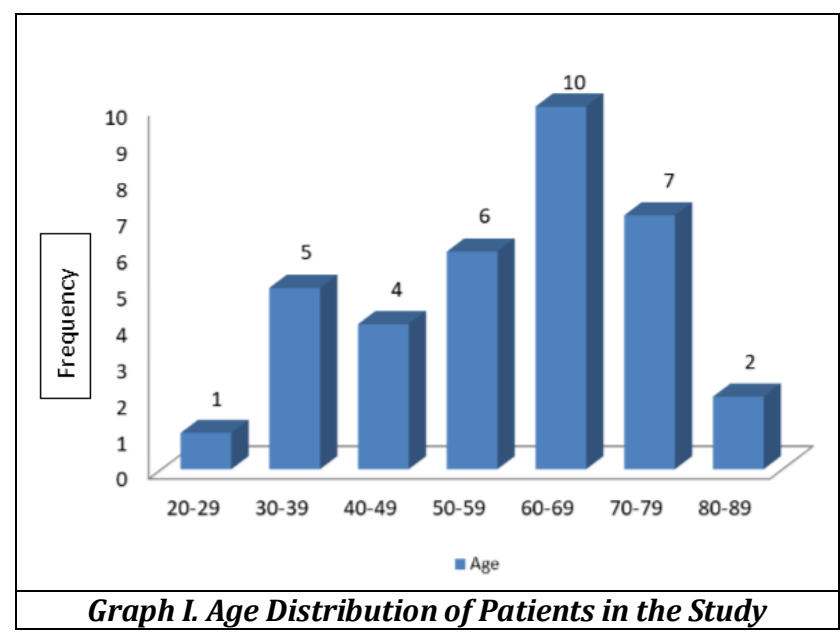

\begin{tabular}{|c|c|c|}
\hline Sl. No. & Duration & Frequency \\
\hline 1 & $<1$ & 9 \\
\hline 2 & $2-6$ & 11 \\
\hline 3 & $7-12$ & 7 \\
\hline 4 & $12-24$ & 2 \\
\hline 5 & $24-36$ & 2 \\
\hline 6 & $>36$ & 4 \\
\hline \multicolumn{2}{|c|}{ Table II. Duration of Stroke } \\
\hline
\end{tabular}

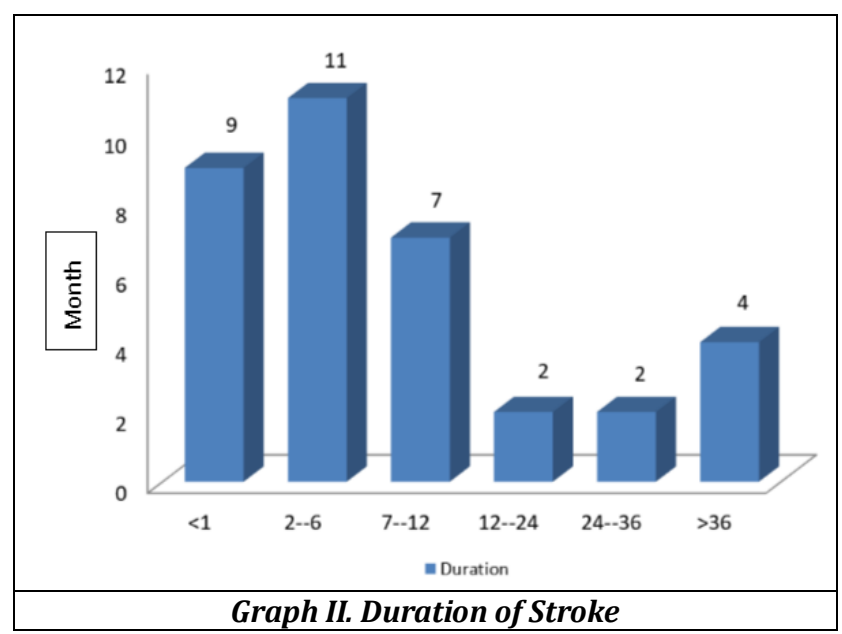




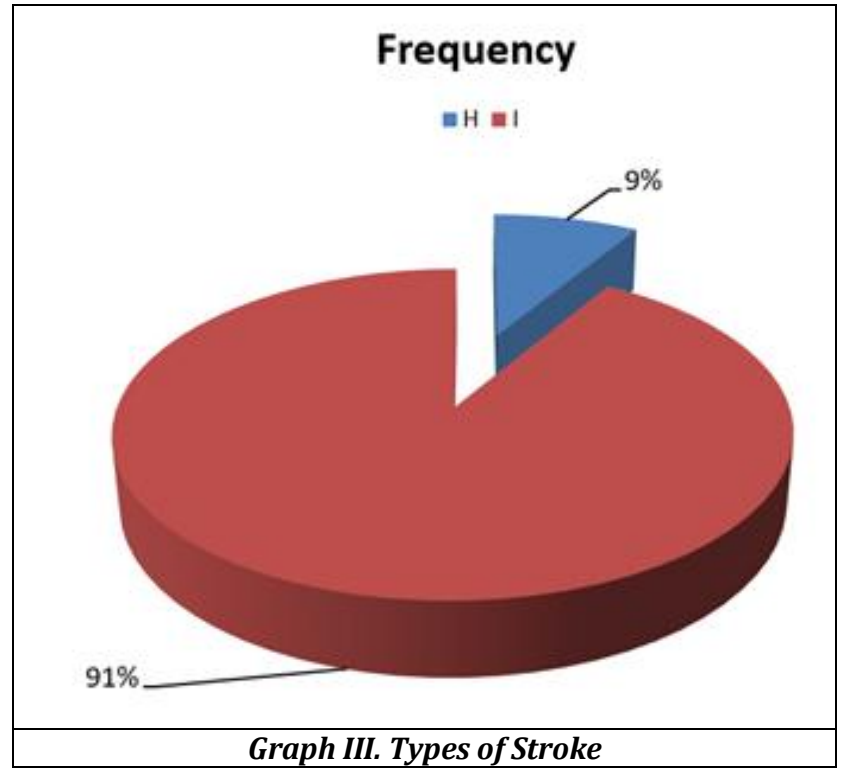

\begin{tabular}{|c|c|c|c|}
\hline Sl. No. & Comorbidity & Frequency & Percent \\
\hline 1 & DM & 4 & 11.4 \\
\hline 2 & DM/HTN & 9 & 25.7 \\
\hline 3 & DM/HTN/DL & 4 & 11.4 \\
\hline 4 & HTN & 10 & 28.6 \\
\hline 5 & HTN/CAD & 1 & 2.9 \\
\hline 6 & HTN/DL & 1 & 2.9 \\
\hline 7 & Nil & 2 & 5.7 \\
\hline 8 & RHD & 3 & 8.6 \\
\hline 9 & Vasculitis & 1 & 2.9 \\
\hline \multicolumn{2}{|c|}{ Total } & $\mathbf{3 5}$ & $\mathbf{1 0 0}$ \\
\hline
\end{tabular}

Table III. USG Measurement of Biceps Tendon Thickness

\begin{tabular}{|c|c|c|c|c|c|c|}
\hline \begin{tabular}{|c|} 
Sl. \\
No. \\
\end{tabular} & Variable & $\begin{array}{c}\text { Visit } \\
1\end{array}$ & $\begin{array}{c}\text { Visit } \\
2 \\
\end{array}$ & $\begin{array}{c}\text { Visit } \\
3 \\
\end{array}$ & \begin{tabular}{|c|} 
Visit \\
4 \\
\end{tabular} & $\begin{array}{c}\text { p- } \\
\text { value }\end{array}$ \\
\hline 1 & $\begin{array}{l}\text { Biceps tendon- } \\
\text { affected side }\end{array}$ & $\begin{array}{c}0.32 \pm \\
0.30\end{array}$ & $\begin{array}{c}0.26 \pm \\
0.19\end{array}$ & $\begin{array}{c}0.21 \pm \\
0.09\end{array}$ & $\begin{array}{c}0.19 \pm \\
0.07\end{array}$ & $\begin{array}{c}<0.000 \\
1\end{array}$ \\
\hline 2 & $\begin{array}{l}\text { Biceps tendon- } \\
\text { unaffected } \\
\text { side }\end{array}$ & $\begin{array}{c}0.16 \pm \\
0.54\end{array}$ & $\begin{array}{c}0.16 \pm \\
0.54\end{array}$ & $\begin{array}{c}0.16 \pm \\
0.54\end{array}$ & $\begin{array}{c}0.16 \pm \\
0.54\end{array}$ & $=1$ \\
\hline \multicolumn{7}{|c|}{ Table IV } \\
\hline
\end{tabular}

Biceps tendon thickness measured sonologically at periodic intervals showed significant improvement $\quad(p$ value 0.0001) at affected side following structured rehab programme. Tendon size on the unaffected side remained the same.

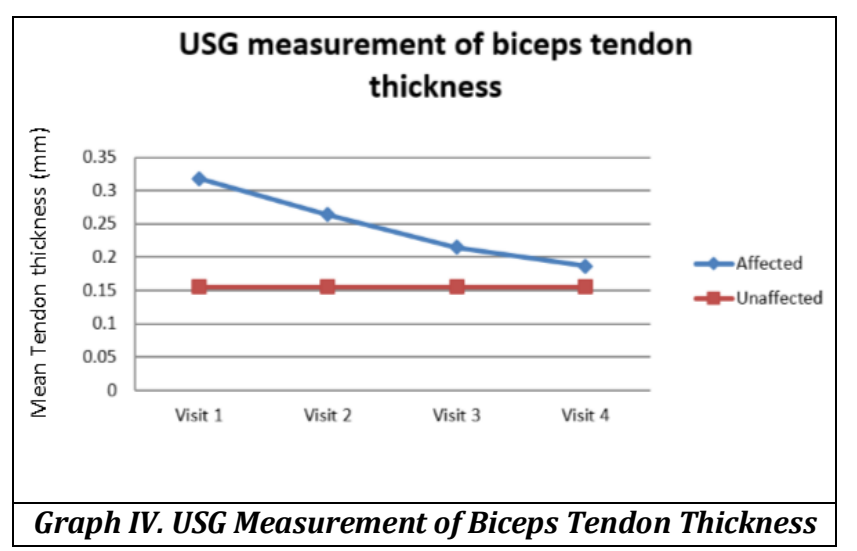

\begin{tabular}{|c|c|c|c|c|c|c|}
\hline $\begin{array}{c}\text { Sl. } \\
\text { No. }\end{array}$ & Variable & $\begin{array}{c}\text { Visit } \\
\mathbf{1}\end{array}$ & $\begin{array}{c}\text { Visit } \\
\mathbf{2}\end{array}$ & $\begin{array}{c}\text { Visit } \\
\mathbf{3}\end{array}$ & $\begin{array}{c}\text { Visit } \\
\mathbf{4}\end{array}$ & $\begin{array}{c}\text { P- } \\
\text { value }\end{array}$ \\
\hline \multirow{2}{*}{1} & Rotator Cuff: - & $0.68 \pm$ & $0.67 \pm$ & $0.66 \pm$ & $0.65 \pm$ & $<0.0001$ \\
& affected side & 0.08 & 0.08 & 0.07 & 0.0 & \\
\hline \multirow{2}{*}{2} & Rotator cuff: - & $0.64 \pm$ & $0.64 \pm$ & $0.64 \pm$ & $0.64 \pm$ & $=1$ \\
& unaffected side & 0.05 & 0.05 & 0.05 & 0.05 & $=1$ \\
\hline
\end{tabular}

Ultrasonographic measurement of rotator cuff tendon thickness on affected side showed significant improvement following the rehabilitation programme ( $p$ value being 0.0001), change at unaffected side was insignificant.
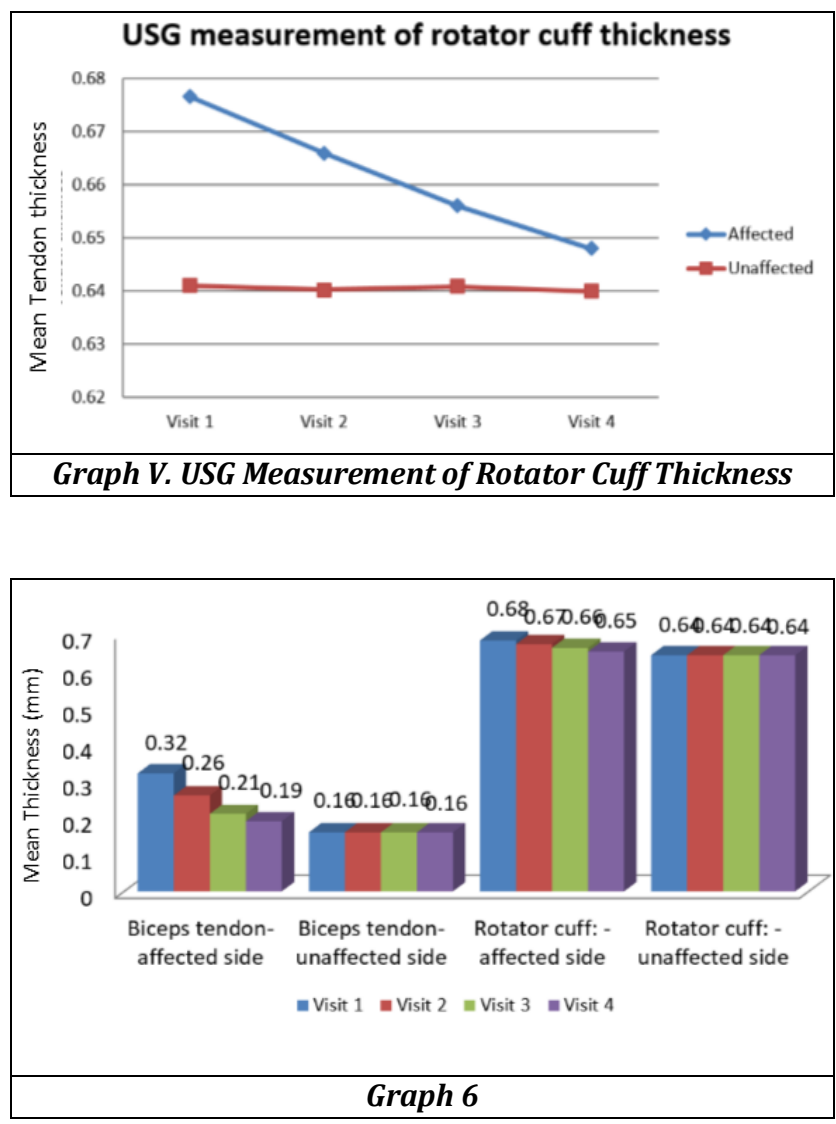

\begin{tabular}{|c|c|c|c|c|}
\hline Sl. No. & $\begin{array}{c}\text { USG Biceps } \\
\text { Tendon }\end{array}$ & $\begin{array}{c}\text { Paired } \\
\text { Mean }\end{array}$ & t & $\begin{array}{c}\text { Sig } \\
\text { (2-Tailed) }\end{array}$ \\
\hline 1 & Visit 2 Vs Visit 1 & .05 & 2.573 & .015 \\
\hline 2 & Visit 3 Vs Visit 1 & .1032 & 2.724 & .01 \\
\hline 3 & Visit 4 Vs Visit 1 & .1314 & 3.024 & .005 \\
\hline Post Hoc Analysis between Visits for USG Biceps Tendon \\
Affected Side \\
\hline
\end{tabular}

\begin{tabular}{|c|c|c|c|c|}
\hline Sl. No. & $\begin{array}{c}\text { USG Rotator } \\
\text { Cuff }\end{array}$ & $\begin{array}{c}\text { Paired } \\
\text { Mean }\end{array}$ & t & $\begin{array}{c}\text { Sig } \\
\text { (2-Tailed) }\end{array}$ \\
\hline 1 & Visit 2 Vs Visit 1 & .0106 & 3.846 & .001 \\
\hline 2 & Visit 3 Vs Visit 1 & .0205 & 4.832 & .0001 \\
\hline 3 & Visit 4 Vs Visit 1 & .0286 & 5.507 & .0001 \\
\hline \multicolumn{4}{|c|}{ Post Hoc Analysis between Visits for USG Rotator Cuff } \\
Affected Side \\
\hline
\end{tabular}




\begin{tabular}{|c|c|c|c|c|c|}
\hline \multirow{4}{*}{ Variable } & $\begin{array}{c}\text { Pearson } \\
\text { Correlation } \\
\text { Significance } \\
\text { (2 tailed) }\end{array}$ & \multicolumn{4}{|c|}{$\begin{array}{c}\text { USG Biceps } \\
\text { Tendon }\end{array}$} \\
\cline { 3 - 6 } & $\mathbf{1}$ & $\begin{array}{c}\text { Visit } \\
\mathbf{2}\end{array}$ & $\begin{array}{c}\text { Visit } \\
\mathbf{3}\end{array}$ & $\begin{array}{c}\text { Visit } \\
\mathbf{4}\end{array}$ \\
\hline \multirow{2}{*}{$\begin{array}{c}\text { Rotator cuff } \\
\text { Affected side }\end{array}$} & $\begin{array}{c}\text { Pearson } \\
\text { correlation }\end{array}$ & .014 & .039 & .126 & .091 \\
\cline { 2 - 6 } & $\begin{array}{c}\text { Significance } \\
\text { (2 tailed) }\end{array}$ & .938 & .822 & .472 & .604 \\
\hline \multicolumn{3}{|c|}{ Table Correlation Coefficient of Rotator Cuff with Biceps } \\
Tendon
\end{tabular}

Table showed that Correlation was not statistically significant for any of the visits between rotator cuff with Biceps tendon

\section{DISCUSSION}

Written informed consent was obtained from patients who entered into the study group. Each patient was assessed for age, gender, body height and weight, stroke type, anatomical location of lesion, side of hemiplegia, time since stroke, Brunnstrom motor recovery stage, spasticity of affected limb, Range Of Motion of shoulder \& Visual Analogue Scale for shoulder pain. Soft tissue sonological examination was done on the same day.

All patients were given a comprehensive stroke rehab programme which includes active and passive ROM exercises, stretching and strengthening exercises, hand function training, other physical modalities etc. for a period of 3 months.

Patients were reviewed clinically at end of first month, end of second month and at the end of third month and findings recorded.

\section{Follow Up Chart}

\begin{tabular}{|c|c|c|c|}
\hline Month & Day & $\begin{array}{c}\text { Clinical } \\
\text { Examination }\end{array}$ & $\begin{array}{c}\text { Sonological } \\
\text { Examination }\end{array}$ \\
\hline \multirow{2}{*}{1} & 0 & $\checkmark$ & $\checkmark$ \\
\cline { 2 - 4 } & 30 & $\checkmark$ & $\checkmark$ \\
\hline 2 & 60 & $\checkmark$ & $\checkmark$ \\
\hline 3 & 90 & $\checkmark$ & $\checkmark$ \\
\hline
\end{tabular}

Ultrasonographic examination was done on first day and also at the end of first, second and third month of study. The correlations between soft tissue changes at different stages of motor recovery were noted.

The aim is to see whether these can be taken as probable prognostic indicators in recovery of hemiplegic shoulder. The rehabilitation team can carefully schedule exercises/activities that involve those particular soft tissues for an early recovery. On the basis of sonology, physicians can begin an early intervention with modification of rehabilitation programme for a better functional recovery of hemiplegic shoulder within an optimum period.

Total of 35 patients were taken into the study. The institutional ethics committee approved the study. Study period extended from 1st January to $30^{\text {th }}$ November.

Out of the 35 patients, 18 patients were females and 17 were males. Right side was involved in 23 patients and left side in 12 patients. Age of patients in the study ranged between 27 and $83 ; 23$ out of 35 (66 \%) belonged to the age group of $50-$ 79. Duration of stroke varied between 1 week to 12 years; 27 out of 35 patients $(77 \%)$ were having duration less than 1 year. Approximately $90 \%$ of patients were having Infarct. Hypertension was the single most co-morbidity, followed by Diabetes mellitus

1. In the course of study, the initial thickness of rotator cuff tendon did not show variation in unaffected shoulder of stroke patients.

2. The most common ultrasonographic soft tissue pathological change in stroke shoulder was bicipital tendonitis and rotator cuff tendonitis thereby increasing the thickness of corresponding tendons.

3. The increased tendon thickness at first visit was observed in all cases, irrespective of age, gender or duration; however, in the older population, the rate of increase in rotator cuff tendon thickness on affected side was significant.

4. There is significant reduction in biceps tendon thickness during the study period following a structured rehabilitation programme.

5. Rate of increase in rotator cuff tendon size is significantly related to spasticity grade at initial visit.

\section{CONCLUSION}

Soft tissue ultrasonography can be used in the diagnosis of shoulder pain in hemiplegia. Serial evaluation helps in tailoring a structured rehabilitation programme for hemiplegic shoulder.

\section{REFERENCES}

[1] Rizk TE, Christopher RP, Pinals RS, et al. Arthrographic studies in painful hemiplegic shoulders. Arch Phys Med Rehab 1984;65(5):254-6.

[2] Yu D. Shoulder pain in hemiplegia. Phys Med Rehabil Clin N Am 2004;15(3):vi-vii, 683-97.

[3] Gamble GE, Barberan E, Bowsher D, et al. Post stroke shoulder pain: more common than previously realized. Eur J Pain 2000;4(3):313-5.

[4] Rajaratnam BS, Venketasubramanian N, Kumar PV, et al. Predictability of simple clinical tests to identify shoulder pain after stroke. Arch Phys Med Rehabil 2007;88(8):1016-21.

[5] Gold RH, Seeger LL, Yao L. Imaging shoulder impingement. Skeletal Radiol 1993;22(8):555-61.

[6] Hall F. Ultrasonographic evaluation of rotator cuff and biceps tendon (letter). J Bone Joint Surg Am 1986;68(6):950-1.

[7] Shah RR, Haghpanah S, Elovic EP, et al. MRI findings in the painful poststroke shoulder. Stroke 2008;39(6):1808-13.

[8] Gresham GE, Duncan PW, Staston WB, et al. Post-Stroke Rehabilitation Guideline Panel. Post-Stroke Rehabilitation. Clinical Practice Guidelilne No. 16 CAHCPR Publication No. 95-0662), Rockville, MD: U.S. Department of Health and Human Services, Public Health Service, Agency for Health Care Policy and Research, May 1995. 